\title{
Comparative study of the effects of Cassia spectabilis and Newbouldia laevis leaf extracts on diclofenac-induced hepatorenal oxidative damage in rats
}

\author{
Raphael John Ogbe ${ }^{1,2^{*}}$ (D) Carrol Domkat Luka ${ }^{1}$ and Godwin Ichekanu Adoga ${ }^{1}$
}

\begin{abstract}
Background: There is high incidence of liver and kidney diseases worldwide but medicinal plants may provide remedy. This study evaluated and compared the protective effects of Cassia spectabilis extract (CSE) and Newbouldia laevis extract (NLE) against diclofenac (DF) induced hepatorenal oxidative damage in rats.

Methods: Twenty four rats were divided into 4 groups with 6 rats in each. Normal saline was given to the rats in group I while those in groups III and IV were treated with $250 \mathrm{mg} / \mathrm{kg} \mathrm{b.} \mathrm{wt.} \mathrm{CSE} \mathrm{and} \mathrm{NLE} \mathrm{respectively} \mathrm{for} 28$ days by oral gavages. Those in groups II to IV were exposed to $10 \mathrm{mg} / \mathrm{kg}$ DF in the last 7 days of treatment. Serum was separated from the blood and used for estimations of hepatorenal injury markers while the homogenized tissue supernatants were used for assays of oxidative stress markers.

Results: There was a significant $(p<0.01)$ increase in the levels of ALT, AST, GGT, MDA, creatinine and BUN but a significant $(p<0.01)$ decrease in the levels of SOD, CAT, GPx, GST, GSH and G6Pase of DF-exposed rats when compared with normal control. However, treatment of DF-exposed rats with CSE and NLE significantly $(p<0.01)$ increased the levels of SOD, CAT, GPx, GST, GSH, and G6Pase but significantly $(p<0.01)$ reduced the levels of ALT, AST, GGT, MDA, creatinine and BUN when compared with DF control.

Conclusion: The current findings showed that treatments with CSE and NLE may have protective effects against DF-induced hepatorenal oxidative damage in rats, attributed to certain phytochemicals, but CSE has greater bioactivity than NLE.
\end{abstract}

Keywords: Hepatoprotective, Lipid peroxidation, Phytochemicals, Radicals, Renoprotective

\section{Introduction}

Liver and kidney diseases are major global health problems, posing great challenges to several countries, especially the developing nations of the world $[1,2]$. Several hepatorenal disorders are caused by drug-induced toxicities in animals $[2,3]$. Diclofenac sodium (DF) is among

\footnotetext{
*Correspondence: ralphjohn2012@gmail.com; ogbe.raphael@uam.edu.ng ${ }^{1}$ Department of Biochemistry, Faculty of Basic Medical Sciences, University of Jos, Jos, Nigeria

${ }^{2}$ Department of Veterinary Physiology and Biochemistry, College of Veterinary Medicine, Federal University of Agriculture, Makurdi P. M. B. 2373, Nigeria
}

the drugs reported to cause adverse effects in the liver and kidney of animals [2, 4]. It is a phenyl acetic acid derivative, developed as a non-steroidal anti-inflammatory lites, 5-hydroxy dictofer nac. These metabolites may increase the levels of oxidants and free radicals known as reactive oxygen species (ROS), which result in oxidative stress and cause damage to hepatorenal tissues in rats [6]. Oxidative stress occurs when there is disruption in the balance 
between ROS such as superoxide anion radicals, hydroxyl radicals, nitric oxide and hydrogen peroxide and the antioxidant like reduced glutathione which neutralizes them [7].

The liver is the main organ which performs the function of xenobiotic metabolism, assisted by the kidneys, lungs and gastrointestinal tract [8]. The biochemical modifications of foreign compounds, drugs and environmental pollutants by the liver of animals, make it susceptible to toxic effects [9]. The kidney is the major organ responsible for excretion of metabolic waste products in animals [10]. Thus, it is vulnerable to oxidative damage because of oxidative stress caused by ROS, which attack polyunsaturated fatty acids in the renal membrane lipids, resulting in lipid peroxidation [11]. Drug-induced liver injury is estimated to have an annual incidence of 10 to 15 per 10,000 to 100 , 000 persons exposed to prescription drugs [12]. The global prevalence of chronic kidney disease (CKD) is estimated to be 11-13\% [13]. The 2010 global burden of disease study reported that CKD was ranked 27th in the list of diseases which caused total number of deaths worldwide in 1990 but moved to 18th in 2010 [14]. It was estimated that nearly two million people die of acute kidney injury (AKI) every year worldwide [15].

Cassia spectabilis (DC.) Irwin \& Barn. - is a leguminous plant species in the family, Fabaceae, and subfamily, Caesalpinioideae [16]. It is a tropical plant known by the common name, "Golden cassia", but in Nigeria it is called "Okpehekwu", by the Idoma people of Benue state. The trees are rounded in shape, have evergreen foliage, with the height of $15-20 \mathrm{ft}$. The leaves are compound green, flowers are showy and yellow, but the bark is gray and smooth [17]. The plant products are used as laxative and purgative, and as traditional medicines for treatment of flu and cold [18]. Scientific studies have shown that the plant extract has radical scavenging activity [16], antifungal and antimicrobial activities [18].

Newbouldia laevis P. Beauv: (Family: Bignoniaceae) - is a medium sized angiosperm or tree, which can grow to a height of about $10 \mathrm{~m}$. It is a tropical plant and widespread from Guinea Savanna to the rain forests of Africa. The English/trade names are "African border tree", "Smooth Newbouldia" or "Fertility tree", but in Nigeria it is called "Ogblichi" (Idoma), "Akoko" (Yoruba), "Ogirisi" (Igbo) and "Aduruku" (Hausa) [19]. The leaves are waxy, dark green, while the flowers are tubular, pink and come in bunches [20]. The roots and leaves are used for treatment of diseases such as fever, headache, convulsion and epilepsy [21]. Scientific studies have shown that its stem bark has radical scavenging effect on certain free radicals [22], while different parts of the plant possess antimicrobial activities [23].

There seems to be paucity of scientific reports on the protective effects of these plant leaf extracts against hepatorenal oxidative damage in drug-exposed rats, but traditional medicine practitioners claimed they are effective in the management of liver and kidney disorders in humans. Therefore, this study was designed to evaluate the protective effects of $C$. spectabilis and $N$. laevis leaf extracts against DF-induced hepatorenal oxidative damage in rats and compare their bioactivities.

\section{Materials and methods}

Chemicals and reagents

Diclofenac sodium is an injectable liquid purchased from North China Pharmaceutical Co. Ltd., 115 Hainan Road, Shijiazhuang, Hebei, China while 2, 2 - diphenyl-1-picryl hydrazine (DPPH) was purchased from Sigma-Aldrich, U.S.A. Biochemical tests reagent kits were purchased from Randox Laboratories, UK. All the reagents used are of analytical grade.

\section{Preparation of diclofenac sodium}

Each $3 \mathrm{ml}$ ampoule contains $75 \mathrm{mg}$ of diclofenac sodium. A single dose of the drug was suspended in $0.2 \mathrm{ml}$ of normal saline $(0.9 \mathrm{~g} / \mathrm{dL} \mathrm{NaCl})$, which served as a vehicle for the drug.

\section{Preparation of Cassia spectabilis and Newbouldia laevis leaf extracts}

The C. spectabilis and N. laevis leaves were harvested from a forest in Obu, Otukpa, in Benue state. They were identified and authenticated by Mr. Mark Uleh, a Lecturer/Taxonomist in the Department of Forestry and Forest Products, Federal University of Agriculture, Makurdi, Nigeria. The voucher specimens were deposited in the College of Forestry herbarium, with voucher numbers given as: C. spectabilis - FH/0258 and N. laevis - FH/0202. The leaves were dried at room temperature for at least three weeks, pulverized to fine particles with mortar and pestle, and sieved with a porcelain sieve. The preparation of plant extracts was done according to the method of Abu and Uchendu [24]. Aqueous ethanol mixture was prepared by adding $800 \mathrm{ml}$ distilled water to $200 \mathrm{ml}$ absolute ethanol and mixed thoroughly. Then, $200 \mathrm{~g}$ of the powdered sample was macerated in $1200 \mathrm{ml}$ of aqueous ethanol solvent and allowed to stand for $72 \mathrm{~h}$. The mixture was sieved with a clean piece of cloth and filtered with Whatman no. 1 filter papers. The filtrate was placed on water bath for the solvent to evaporate at $50^{\circ} \mathrm{C}$, while the extract was dried to a constant weight in a desiccator and the weight was determined.

\section{Experimental animals and management}

Albino Wistar rats, Rattus norvegicus, were purchased from the Animal house, College of Health sciences, Benue State University, Makurdi, Nigeria. Equal numbers of male and female rats, weighing between 200 and $250 \mathrm{~g}$ were 
used for this study. They were allowed to acclimatize for at least three weeks in the Department of Veterinary Physiology and Biochemistry research laboratory, Federal University of Agriculture, Makurdi, Nigeria; under normal environmental conditions of $12 \mathrm{~h}$ dark and $12 \mathrm{~h}$ light cycle, with an average temperature of $29^{\circ} \mathrm{C}$. They were fed with standard animal feeds, produced by Grand Cereal and Oil Mills Ltd., Jos, Nigeria and clean water ad libitum. The rats were treated with care according to the International guidelines and principles for biomedical research involving animals [25].

\section{Phytochemical analyses of C. spectabilis and N. laevis leaf extracts}

Aqueous ethanol (2:1) extracts of C. spectabilis and $N$. laevis leaves were prepared by maceration of $10 \mathrm{~g}$ pulverized sample in a mixture of $100 \mathrm{ml}$ distilled water and $50 \mathrm{ml}$ ethanol in a conical flask, covered with aluminum foil. After $48 \mathrm{~h}$, the mixture was filtered with filter papers and the filtrate tested for phytochemical constituents, according to the methods earlier described [26, 27].

\section{Scavenging effects of CSE and NLE on 2, 2-diphenyl-1- picryl hydrazyl radicals}

The radical scavenging effect (RSE) of CSE and NLE on $\mathrm{DPPH}$ radicals were determined by a method previously described [28]. Briefly, the concentrations of CSE and NLE were prepared as $0.05,0.1,0.2,0.5,1.0,2.0$, and 5.0 $\mathrm{mg} / \mathrm{ml}$ in methanol. Similar concentrations of ascorbic acid were also prepared. Then, $1 \mathrm{ml}$ of plant extract/ascorbic acid was placed in a test tube and $3 \mathrm{ml}$ methanol added, followed by $0.5 \mathrm{ml}$ of $1 \mathrm{mM} \mathrm{DPPH}$ in methanol. A blank solution was prepared which contains the same quantity of methanol and DPPH. After $10 \mathrm{~min}$, the decrease in absorption was measured against the blank by UV-Visible spectrophotometer at $517 \mathrm{~nm}$, and the percentage inhibition was determined. All the tests were performed in duplicates and the mean values were calculated. The RSE of CSE and NLE were expressed as percentage inhibition of DPPH radicals using the equation below:

Percentage inhibition $(\%)=\frac{\text { Absorbance of blank-Absorbance of test }}{\text { Absorbance of blank }} \times 100$

\section{Animal grouping and treatments}

Twenty four adult rats were completely randomized into 4 groups, with 6 rats per group. Group I - rats received $0.2 \mathrm{ml}$ of normal saline by intramuscular (i.m.) route for 7 consecutive days, and served as normal control. Group II - rats received $10 \mathrm{mg} / \mathrm{kg}$ body weight diclofenac (DF) in $0.2 \mathrm{ml}$ normal saline by i.m. for 7 days, and served as diclofenac control. Groups III and IV - rats were treated with $250 \mathrm{mg} / \mathrm{kg}$ b. wt. CSE and NLE respectively by daily oral gavages for 28 days, and exposed to DF in the last 7 days of treatment as in group II.

\section{Collection and preparation of serum and tissue samples}

About $24 \mathrm{~h}$ after treatment, blood was collected from rats by intra-cardiac puncture, under ether anesthesia. The blood was allowed to stand for at least one hour, and centrifuged at $3000 \mathrm{rpm}$ for $10 \mathrm{~min}$. Thereafter, serum was separated with clean Pasteur pipettes and used for biochemical assays. The rats were euthanized, their liver and kidneys were excised, rinsed to remove blood and placed in ice cold dextrose saline solution overnight before being used. The liver and kidney were homogenized separately in $0.1 \mathrm{M}$ phosphate buffer $(\mathrm{pH}$ 7.4), and the homogenate centrifuged at 10,000 rpm for $15 \mathrm{~min}$ in a cold ultracentrifuge at $4{ }^{\circ} \mathrm{C}$. Then, the supernatant was separated and used for estimation of oxidative stress markers.

\section{Biochemical analyses}

Biochemical assays of serum aspartate aminotransferase (AST) and alanine aminotransferase (ALT) [29], gamma glutamyl transferase (GGT) [30], total protein [31], albumin [32], creatinine [33], and BUN [34], were performed according to the procedures in the reagent kits manuals produced by Randox Laboratories Ltd., UK. The absorbance of each test was determined with UV-VIS spectrophotometer at appropriate wavelength and time. The Globulin level was determined by taking the difference between total protein and albumin values of the same sample as earlier described [4]. The activities of glucose 6phosphatase (G6Pase) [35], super oxide dismutase (SOD) [36], catalase (CAT) [37], glutathione peroxidase (GPx) [38], glutathione S-transferase (GST) [39]; and the levels of malon dialdehyde (MDA) [40] and reduced glutathione (GSH) [41] in serum, liver and kidney tissues were determined by standard methods as previously described.

\section{Statistical analyses}

The Statistical Package for Social Sciences (SPSS version 21) software produced by IBM Corp. Ltd. was used for data analysis. Data were expressed as Mean \pm Standard Error of mean (SEM), with $n=6$. They were analyzed by one way analysis of variance (ANOVA) and the level of significance determined by Fischer's least significant difference (LSD) in a Post Hoc test. The differences between mean values were considered significant at $p<0.01$.

\section{Results}

Phytochemical constituents and radical scavenging effects of CSE and NLE on DPPH radicals

The phytochemical constituents of CSE include alkaloids, flavonoids, saponins, tannins, phlobatannins, reducing sugars, anthraquinones and phenols. The phytochemical 
constituents of NLE include saponins, anthraquinones, tannins, reducing sugars and phenols.

The greatest radical scavenging effects of CSE and NLE on DPPH radicals were seen at $2.0 \mathrm{mg} / \mathrm{ml}$, expressed as percentage inhibitions of radicals at $66.9 \%$ and $72.45 \%$ respectively, which are close to the standard, ascorbic acid, with percentage inhibition of $90.4 \%$ (Table 1). The $\mathrm{IC}_{50}$ (concentration of extract which produced $50 \%$ inhibition of DPPH radicals) of CSE and NLE are $5.0 \mathrm{mg} / \mathrm{ml}$ and $4.9 \mathrm{mg} / \mathrm{ml}$ respectively.

\section{Effect of CSE and NLE on antioxidant status and oxidative} stress markers in liver and kidney of rats

There was a significant $(p<0.01)$ decrease in the activities of liver and kidney CAT, SOD, GPx and GST of DFexposed rats when compared with normal control. However, treatment of DF-exposed rats with CSE and NLE significantly $(p<0.01)$ elevated the activities of these antioxidant enzymes compared with DF control (Table 2).

There was a significant $(p<0.01)$ elevation in the levels of liver and kidney tissues lipid peroxidation product, malon dialdehyde (MDA), and significant $(p<0.01)$ reduction in protein, G6Pase and GSH levels of DFexposed rats when compared with normal control. However, treatment of DF-exposed rats with CSE and NLE significantly $(p<0.01)$ reduced the levels of MDA, and significantly $(p<0.01)$ increased the levels of protein, G6Pase and GSH compared with DF control (Table 3).

\section{Effect of CSE and NLE on serum markers of hepatorenal oxidative damage in rats}

There was a significant $(p<0.01)$ elevation in serum ALT, AST, GGT, MDA, BUN and creatinine levels but a significant $(p<0.01)$ reduction in the levels of $\mathrm{GSH}$, SOD, CAT, GPx, GST, G6Pase, total proteins, albumin and globulins of DF-exposed rats when compared with normal control. However, treatment of DF-exposed rats with $250 \mathrm{mg} / \mathrm{kg}$ CSE and NLE significantly $(p<0.01)$ reduced their serum ALT, AST, GGT, MDA, BUN and

Table 1 Radical scavenging effects of CSE and NLE on DPPH radicals

\begin{tabular}{llll}
\hline $\begin{array}{l}\text { Concentration } \\
(\mathrm{mg} / \mathrm{ml})\end{array}$ & \multicolumn{3}{l}{ Percentage inhibition of DPPH radicals } \\
\cline { 2 - 4 } & $\begin{array}{l}\text { \% Inhibition by } \\
\text { Ascorbic acid }\end{array}$ & $\begin{array}{l}\text { \% Inhibition by C. } \\
\text { spectabilis extract }\end{array}$ & $\begin{array}{l}\text { \% Inhibition by } \\
\text { N. laevis extract }\end{array}$ \\
\hline 5 & 85.0 & 49.40 & 51.32 \\
3 & 90.01 & 57.83 & 72.26 \\
2 & 90.41 & 66.90 & 72.45 \\
1 & 91.33 & 66.57 & 59.05 \\
0.5 & 91.32 & 66.87 & 55.09 \\
0.1 & 90.47 & 21.08 & 22.07 \\
0.05 & 90.19 & 0.60 & 21.69 \\
\hline
\end{tabular}

Values are expressed as mean of duplicate readings creatinine levels but significantly $(p<0.01)$ increased their levels of GSH, G6Pase, SOD, CAT, GPx, GST, total proteins, albumin and globulins when compared with DF control (Table 4).

\section{Discussion}

Plant extracts have been used for treatment of several diseases, because they have therapeutic properties and are found to exert biological effects on body tissues [1-3]. The CSE and NLE used in this study contain phytochemicals such as alkaloids, tannins, phenolic compounds and flavonoids. These plant secondary metabolites may be responsible for the protective effects of the extracts against hepatorenal injuries in rats, as they are known to act as antioxidants which scavenge ROS $[1,16]$. The findings of our in vitro study showed that CSE and NLE have radical scavenging effects on DPPH radicals, which agree with reports of previous studies that plant extracts have radical scavenging activities $[15,28]$. Scientific evidence has shown that the medicinal values of plant extracts are due to the activities of their phytochemical constituents such as flavonoids, alkaloids, tannins and terpenoids $[15,16]$.

Drug-induced oxidative damage of hepatorenal tissues in animals is commonly caused by oxidative stress, which is as a result of the effect of excess ROS produced in the tissues [42]. The marked decrease in serum, liver and kidney SOD, CAT, GPx and GST activities after exposure of rats to DF may indicate oxidative stress, which lead to the reduction in antioxidant enzyme activities, may be attributed to the adverse effect of this drug. The drug was earlier found to generate reactive metabolites, 5-hydroxyl diclofenac and N, 5-dihydroxyl diclofenac, which may induce hepatorenal oxidative injuries in animals [6]. These findings are in agreement with earlier reports which showed that ROS produced by drugs may cause imbalance in the generation and elimination of ROS, leading to oxidative stress [42, 43]. However, the significant elevation in the activities of antioxidant enzymes; SOD, CAT, GPx and GST, after treatment of DFexposed rats with CSE and NLE, may suggest that the plant extracts have protective effects against oxidative stress, thereby preventing excessive decrease in activities of antioxidant enzymes in rats. This may be attributed to phytochemicals in the plant extracts, which act as antioxidants and could be utilized in the antioxidant defense system, which consequently may have a sparing effect on the antioxidant enzymes of the animals [7]. These findings are in agreement with reports of previous studies which showed that plant extracts may improve the tissue antioxidant status of drug-exposed rats $[4,15]$.

The marked elevation in serum, liver and kidney levels of MDA but decrease in GSH levels, after the administration of DF to rats may indicate oxidative stress and lipid peroxidation, which may be attributed to the 
Table 2 Effect of CSE and NLE on liver and kidney antioxidant enzymes activities in DF-exposed rats

\begin{tabular}{|c|c|c|c|c|}
\hline \multirow{2}{*}{$\begin{array}{l}\text { Treatment } \\
\text { groups }\end{array}$} & \multicolumn{4}{|c|}{ Levels of liver and kidney antioxidant enzymes in rats } \\
\hline & Catalase $(\mu \mathrm{mol} / \mathrm{min} / \mathrm{mg} \mathrm{p})$ & $\mathrm{SOD}(\mu \mathrm{mol} / \mathrm{min} / \mathrm{mg} \mathrm{p})$ & $\mathrm{GPx}(\mu \mathrm{mol} / \mathrm{min} / \mathrm{mg} \mathrm{p})$ & GST $(\mu \mathrm{mol} / \mathrm{min} / \mathrm{mg} \mathrm{p})$ \\
\hline \multicolumn{5}{|l|}{ Liver } \\
\hline I. Normal saline & $12.55 \pm 0.03$ & $14.27 \pm 0.15$ & $11.04 \pm 0.05$ & $43.07 \pm 0.11$ \\
\hline II. DF + Saline & $3.72 \pm 0.09^{\mathrm{a}}$ & $4.42 \pm 0.02^{\mathrm{a}}$ & $1.81 \pm 0.03^{\mathrm{a}}$ & $18.11 \pm 0.11^{\mathrm{a}}$ \\
\hline III. CSE + DF & $10.91 \pm 0.01^{b}$ & $11.99 \pm 0.06^{b}$ & $7.87 \pm 0.02^{b}$ & $35.25 \pm 0.41^{b}$ \\
\hline IV. NLE + DF & $9.38 \pm 0.02^{b}$ & $5.28 \pm 0.02^{b}$ & $3.86 \pm 0.02^{b}$ & $21.36 \pm 0.21^{b}$ \\
\hline \multicolumn{5}{|l|}{ Kidney } \\
\hline I. Normal saline & $3.12 \pm 0.01$ & $11.24 \pm 0.13$ & $9.46 \pm 0.05$ & $16.91 \pm 0.25$ \\
\hline II. DF + Saline & $0.89 \pm 0.02^{\mathrm{a}}$ & $3.16 \pm 0.03^{a}$ & $1.28 \pm 0.05^{\mathrm{a}}$ & $4.13 \pm 0.09^{\mathrm{a}}$ \\
\hline III. CSE + DF & $2.81 \pm 0.05^{b}$ & $9.52 \pm 0.12^{b}$ & $7.21 \pm 0.05^{b}$ & $14.66 \pm 0.14^{b}$ \\
\hline IV. NLE + DF & $1.19 \pm 0.02^{b}$ & $4.25 \pm 0.02^{b}$ & $3.79 \pm 0.01^{b}$ & $8.03 \pm 0.03^{b}$ \\
\hline
\end{tabular}

Values are Mean $\pm \mathrm{SEM}, n=6$; $P$ Protein, DF Diclofenac sodium, ${ }^{\mathrm{a}}$ significantly different from normal control $(p<0.01)$, ${ }^{\mathrm{b}}$ significantly different from DF control $(p<0.01)$

adverse effects of this drug. The ROS attack on cell membrane lipids or lipoproteins during oxidative stress starts lipid peroxidation, which is implicated in the development of several diseases including drug-induced liver and kidney damage in animals [5, 11, 44]. These findings are in agreement with Owumi and Dim [2] who reported that there were marked elevation in MDA levels and decrease in GSH levels after exposure of animals to DF. However, the marked decrease in levels of MDA and increase in GSH levels after treatment of DF-exposed rats with CSE and NLE may suggest that these plant extracts have protective effects against hepatorenal injuries, which may be attributed to the antioxidant properties of their phytochemicals, which consequently have a sparing effect on GSH, an important endogenous antioxidant. These findings are in accord with the reports by earlier researchers, who demonstrated the antioxidative activities of plant extracts $[4,15]$.
The marked increase in serum AST, ALT, GGT activities and marked decrease in the levels of total protein, albumin and globulin, after exposure of rats to DF may be indicative of hepatocellular and hepatobiliary injuries in rats, attributed to the adverse effects of the drug. These findings are in agreement with earlier studies which demonstrated that the alteration of these enzymes activities is a signal of an underlying pathological process, thus they are used as biomarkers of hepatic tissue injuries in animals $[2,4,16]$. The serum aminotransferases activities are elevated in all cases of liver diseases $[2,5]$. The normal activities of these enzymes in blood are very low but when there is necrosis of liver cells, they leak out into the systemic circulation, thus their activities are increased in blood [2]. Albumin and total protein have earlier been reported to decrease as a result of damage to liver tissues, leading to reduced synthetic functions of liver, which was attributed to drug-induced hepatotoxicity [4].

Table 3 Effect of CSE and NLE on levels of Proteins, MDA, GSH and G6Pase in hepatorenal tissues of DF-exposed rats

\begin{tabular}{|c|c|c|c|c|}
\hline \multirow{2}{*}{$\begin{array}{l}\text { Treatment } \\
\text { groups }\end{array}$} & \multicolumn{4}{|c|}{ Levels of hepatorenal oxidative injuries markers in rats } \\
\hline & $\overline{\mathrm{MDA}}(\mathrm{nmol} / \mathrm{mg} \mathrm{p})$ & Protein $(\mathrm{g} / \mathrm{L})$ & $\mathrm{GSH}(\mu \mathrm{g} / \mathrm{mg} \mathrm{p})$ & G6Pase (U/mg p) \\
\hline \multicolumn{5}{|l|}{ Liver } \\
\hline I. Normal saline & $1.99 \pm 0.01$ & $164.41 \pm 0.29$ & $64.65 \pm 0.18$ & $28.82 \pm 0.25$ \\
\hline II. DF + Saline & $15.43 \pm 0.19^{a}$ & $121.07 \pm 0.06^{\mathrm{a}}$ & $30.30 \pm 0.23^{\mathrm{a}}$ & $14.62 \pm 0.02^{\mathrm{a}}$ \\
\hline III. CSE + DF & $7.11 \pm 0.01^{\mathrm{b}}$ & $148.16 \pm 0.10^{b}$ & $52.48 \pm 0.25^{\mathrm{b}}$ & $21.03 \pm 0.03^{b}$ \\
\hline IV. NLE + DF & $11.10 \pm 0.06^{b}$ & $135.40 \pm 0.16^{b}$ & $39.15 \pm 0.08^{b}$ & $14.04 \pm 0.04^{\mathrm{a}}$ \\
\hline \multicolumn{5}{|l|}{ Kidney } \\
\hline I. Normal saline & $1.75 \pm 0.03$ & $163.11 \pm 0.30$ & $12.46 \pm 0.2$ & $23.55 \pm 0.43$ \\
\hline II. DF + Saline & $8.68 \pm 0.20^{\mathrm{a}}$ & $82.73 \pm 0.47^{\mathrm{a}}$ & $4.76 \pm 0.03^{\mathrm{a}}$ & $9.59 \pm 0.12^{\mathrm{a}}$ \\
\hline III. CSE + DF & $3.23 \pm 0.10^{b}$ & $144.52 \pm 0.29^{b}$ & $9.04 \pm 0.04^{b}$ & $17.28 \pm 0.22^{b}$ \\
\hline IV. NLE + DF & $6.12 \pm 0.01^{b}$ & $132.14 \pm 0.21^{b}$ & $5.34 \pm 0.03^{b}$ & $11.01 \pm 0.02^{\mathrm{b}}$ \\
\hline
\end{tabular}

Values are Mean \pm SEM, $n=6$; DF Diclofenac sodium, ${ }^{a}$ significantly different from normal control $(p<0.01)$, ${ }^{b}$ significantly different from diclofenac control $(p<0.01)$ 
Table 4 Effect of CSE and NLE on serum markers of hepatorenal oxidative damage in DF-exposed rats

\begin{tabular}{|c|c|c|c|c|}
\hline \multirow{2}{*}{$\begin{array}{l}\text { Biochemical } \\
\text { parameters }\end{array}$} & \multicolumn{4}{|l|}{ Treatment groups } \\
\hline & I. Normal control & II. 10 mg/kg DF + Saline & III. $250 \mathrm{mg} / \mathrm{kg}$ CSE + DF & IV. $250 \mathrm{mg} / \mathrm{kg}$ NLE + DF \\
\hline$\overline{\mathrm{ALT}}(\mathrm{U} / \mathrm{L})$ & $8.92 \pm 0.05$ & $80.94 \pm 0.74^{a}$ & $15.72 \pm 0.18^{b}$ & $27.2 \pm 0.40^{b}$ \\
\hline AST (U/L) & $14.06 \pm 0.05$ & $124.91 \pm 0.53^{\mathrm{a}}$ & $20.66 \pm 0.19^{b}$ & $36.6 \pm 0.20^{b}$ \\
\hline GGT (U/L) & $39.97 \pm 0.10$ & $125.39 \pm 0.22^{\mathrm{a}}$ & $47.73 \pm 0.18^{b}$ & $66.7 \pm 0.16^{b}$ \\
\hline G6Pase (U/L) & $33.35 \pm 0.46$ & $14.07 \pm 0.10^{\mathrm{a}}$ & $27.06 \pm 0.28^{b}$ & $18.0 \pm 0.18^{b}$ \\
\hline Protein $(\mathrm{g} / \mathrm{dl}) \times 10^{-2}$ & $16.0 \pm 0.78$ & $7.0 \pm 0.44^{\mathrm{a}}$ & $13.0 \pm 2.35^{\mathrm{b}}$ & $10.0 \pm 0.29^{b}$ \\
\hline Albumin $(\mathrm{g} / \mathrm{dl}) \times 10^{-2}$ & $4.0 \pm 0.24$ & $2.0 \pm 0.34^{a}$ & $4.0 \pm 0.26^{b}$ & $3.0 \pm 0.18^{b}$ \\
\hline Globulin $(\mathrm{g} / \mathrm{dl}) \times 10^{-2}$ & $12.0 \pm 0.91$ & $5.0 \pm 0.19^{a}$ & $9.0 \pm 2.35^{b}$ & $7.0 \pm 0.29^{b}$ \\
\hline BUN (mmol/L) & $5.03 \pm 0.04$ & $34.23 \pm 0.81^{\mathrm{a}}$ & $6.47 \pm 0.10^{b}$ & $20.8 \pm 0.24^{b}$ \\
\hline Creatinine ( $\mu \mathrm{mol} / \mathrm{L})$ & $100.6 \pm 0.43$ & $481.2 \pm 5.64^{\mathrm{a}}$ & $123.6 \pm 0.23^{b}$ & $341.1 \pm 0.32^{b}$ \\
\hline $\mathrm{MDA}(\mathrm{nmol} / \mathrm{mg} \mathrm{p})$ & $2.96 \pm 0.03$ & $12.51 \pm 0.22^{\mathrm{a}}$ & $4.66 \pm 0.05^{b}$ & $8.01 \pm 0.08^{b}$ \\
\hline $\mathrm{GSH}(\mu \mathrm{g} / \mathrm{ml})$ & $60.49 \pm 0.53$ & $30.67 \pm 0.27^{\mathrm{a}}$ & $48.15 \pm 0.27^{b}$ & $36.3 \pm 0.21^{b}$ \\
\hline $\mathrm{SOD}(\mathrm{U} / \mathrm{mg} \mathrm{p})$ & $11.29 \pm 0.11$ & $3.60 \pm 0.07^{\mathrm{a}}$ & $8.99 \pm 0.08^{b}$ & $6.10 \pm 0.02^{b}$ \\
\hline CAT (U/mg p) & $8.99 \pm 0.08$ & $2.02 \pm 0.05^{a}$ & $6.10 \pm 0.03^{b}$ & $6.17 \pm 0.03^{b}$ \\
\hline $\operatorname{GPx}(\mathrm{U} / \mathrm{mg} \mathrm{p})$ & $9.13 \pm 0.25$ & $2.39 \pm 0.02^{\mathrm{a}}$ & $6.24 \pm 0.04^{b}$ & $4.46 \pm 0.25^{b}$ \\
\hline GST (U/mg p) & $41.05 \pm 0.59$ & $15.17 \pm 0.19^{a}$ & $31.99 \pm 0.68^{b}$ & $19.14 \pm 0.24^{b}$ \\
\hline
\end{tabular}

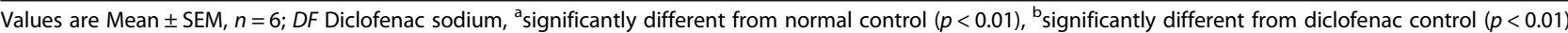

The marked elevation in the levels of serum creatinine and BUN after the exposure of rats to DF may be indication of renal tissue injuries, which can be attributed to the adverse effects of this drug. The marked reduction in serum, liver and kidney G6Pase activities after exposure of rats to DF may suggest hepatorenal tissue damage, which consequently lead to a decrease in the enzyme activity; may be attributed to the adverse effects of reactive metabolites produced by the drug. These findings are in agreement with Owumi and Dim [2] who reported that DF is a powerful drug which causes nephrotoxicity, and this was demonstrated by the increases of serum creatinine and urea levels in rats. Konda et al. [15] also found that there were elevations in serum creatinine and BUN levels of rats after they were exposed to a drug. The reduced G6Pase activity is in agreement with Kumashiro et al. [45] who found that accumulation of ROS reduced the expression level of G6Pase in hepatocytes of animals after they were exposed to a toxin.

The marked decrease in serum AST, ALT and GGT activities by treatment of DF-exposed rats with CSE and NLE may suggest that these plant extracts have protective effects against DF-induced hepatocellular and hepatobiliary injuries in rats. The reports of previous studies have shown that plant extracts have protective effects against drug-induced liver damage in animals while others may reverse the elevation of serum enzymes to near normal values $[4,16]$. The marked reduction in the levels of serum creatinine and BUN after treatment of DF-exposed rats with CSE and NLE may suggest that the plant extracts have protective effects against renal tissue damage in rats and may promote the rapid healing of the tissue injuries. The marked increase in serum, liver and kidney G6Pase activities after treatment of DFexposed rats with both plant extracts may suggest that the extracts have protective effects against hepatorenal tissue damage in rats, which may prevent sharp decrease in the activity of this enzyme, which plays important roles in glucose metabolism. These findings are in agreement with several studies which showed that plant extracts may have protective effects against drug-induced hepatorenal tissue injuries in rats $[1,3,4,15]$.

\section{Conclusion}

This study has shown that CSE and NLE may have protective effects against DF-induced acute hepatorenal oxidative damage in rats, however CSE has greater bioactivity than NLE. The activities of these plant extracts may be attributed to their phytochemicals, which act as potent antioxidants that can scavenge ROS, capable of causing oxidative damage to animal tissues. These findings have given credence to the use of these plant extracts in traditional medicine, for the management of liver and kidney diseases in humans. However, there is need to conduct bioassay-guided fractionation and characterization of bioactive compounds responsible for the medicinal properties of these plant extracts.

\section{Abbreviations}

CSE: Cassia spectabilis leaf extract; NLE: Newbouldia laevis leaf extract; DF: Diclofenac sodium; GFR: Glomerular filtration rate; ROS: Reactive oxygen species; RNS: Reactive nitrogen species; DPPH-2: 2-diphenyl-1-picryl hydrazyl 
radicals; LSD: Least significant difference; NSAID: Non steroidal antiinflammatory drug

\section{Acknowledgements}

Not applicable.

\section{Authors' contributions}

RJO and GIA designed the experiment while GIA and CDL supervised it. RJO conducted the biochemical, histologicaldelete and, statistical analyses, and interpreted the results. RJO wrote the first draft of this manuscript while GIA and $C D L$ revised the manuscript for intellectual content. All authors read and approved the final draft of the manuscript.

\section{Funding}

This work was supported with a grant by the Tertiary Education Trust Fund (TETFUND), the education-funding agency of the Federal government of Nigeria, through the Federal University of Agriculture, Makurdi, Nigeria.

\section{Availability of data and materials}

The data sets used and/or analyzed during the current study are available from the corresponding author on reasonable request.

\section{Ethics approval and consent to participate}

The protocols of this study were approved by the Animal Welfare and Ethics Committee of the College of Veterinary Medicine, Federal University of Agriculture, Makurdi, Nigeria. The ethical approval was given with a clearance certificate reference number: FUAM/CVM/002.

\section{Consent for publication}

Not applicable.

\section{Competing interests}

The authors declare that they have no competing interests.

Received: 10 January 2020 Accepted: 6 May 2020

Published online: 20 May 2020

\section{References}

1. Das K, Chakraborty PP, Ghosh D, Nandi KD. Protective effect of aqueous extract of Terminalia arjuna against dehydrating induced oxidative stress and uremia in male rats. Iran J Pharm Res. 2010;9(2):153-61.

2. Owumi SE, Dim UJ. Biochemical alterations in diclofenac-treated rats: effect of selenium on oxidative stress, inflammation, and hematological changes. Toxicol Res Appl. 2019; 3:1-10. https://doi.org/10.1177/2397847319874359.

3. Naggayi M, Mukiibi N, lliya E. The protective effects of aqueous extract of Carica papaya seeds in paracetamol-induced nephrotoxicity in male Wista rats. Afr Health Sci. 2015;15(2):598-605. https://doi.org/10.4314/ahs.v5i2.37.

4. Ogbe RJ, Luka CD, Adoga Gl. Effect of aqueous ethanol extract of Dialium guineense leaf on diclofenac-induced oxidative stress and hepatorenal injuries in Wistar rats. Comp Clin Path.2019; 28:241-248. https://doi.org/10. 1007/s00580-018-2822-2

5. Adeyemi WJ, Olayaki LA. Diclofenac-induced hepatotoxicity: Low dose of omega-3 fatty acids have more protective effects. Toxicol Rep. 2018; 5:9095. https://doi.org/10.1016/j.toxrep.2017.12.002

6. Bort R, Ponsoda X, Jover R, Gómez-Lechón MJ, Castell JV. Diclofenac toxicity to hepatocytes: a role for drug metabolism in cell toxicity. J Pharmacol Exp Ther. 1999;288(1):65-72.

7. Pham-Huy LA, He H, Pham-Huy C. Free radicals, antioxidants in disease and health. Int J Biomed Sci. 2008:4(2):89-96.

8. Neal MJ. Drug metabolism. In: Medical pharmacology at a glance. 7th ed. London: Wiley; 2012. p. 14-5.

9. Smith HJ, Williams H. Drug Elimination. In: Smith and Williams Introduction to the principles of drug design and action. 4th ed. New York: CRC Press, Boca Raton; 2005. p. 720.

10. Smith HW. The kidney: structure and function in health and disease. New York: Oxford University press; 1991. p. 336

11. Ozbek E. Induction of oxidative stress in kidney. Int J Nephrol. 2012; 2012:1-9.

12. Lisi DM. Drug-induced liver injury: an overview. US Pharm. 2016;41(12):30-4.

13. Hill NR, Fatoba ST, Oke JL, Hirst JA, O'Callaghan CA, Lasserson DS, Hobbs FDR. Global prevalence of chronic kidney disease - a systematic review and meta-analysis. PLoS One 2016; 11(7):e0158765. https://doi.org/10.1371/ journal.pone.015 8765 .

14. Jha V, Garcia-Garcia G, Iseki K, Li Z, Naicker S, Plattner B, Saran R, Wang AY, Yang CW. Chronic kidney disease: global dimension and perspectives. Lancet. 2013; 382(9888):260-272. https://doi.org/10.1016/S0140-6736(13)60687-x.

15. Konda VR, Arunachalam R, Eerike M, Ramesh RK, Radhakrishnan AK, Raghuraman LP, Meti V, Devi S. Nephroprotective effect of ethanolic extract of Azima tetracantha root in glycerol induced acute renal failure in Wistar rats. J Tradit Complement Med 2016; 6:347-354. https://doi.org/10.1016/j.jtcme.2015.05.001.

16. Jothy SL, Aziz A, Chen Y, Sasidharan S. Antioxidant activity and hepatoprotective potential of Polyalthia longifolia and Cassia spectabilis leaves against paracetamol-induced liver injury. Evid Based Complement Altern Med. 2012; 2012:1-10. https://doi.org/10.1155/2012/561284

17. Omotayo FO. Plants of south western Nigeria. Ibadan: University of Ibadan press; 1999.

18. Sangetha S, Zuraini Z, Sasidharan S, Suryani S. Fungicidal effect and oral acute toxicity of Cassia spectabilis leaf extract. Jap J Medic Mycol. 2008;49: 299-304.

19. Kolawole OT, Akanji MA, Akiibinu MO. Toxicological assessment of ethanolic extract of the leaves of Newbouldia laevis P. Beauv Am J Med Medic Sci. 2013;3(4):74-80

20. Arbonnier M. Trees, shrubs and lianas of west African dry zones. 2004; Abidjan: CIRAD. Margra GMBH.

21. Ainooson GK, Woode E, Obiri DD, Koffou GA. Antinociceptive effects of Newbouldia laevis extracts in a rat model. Afr J Tradit Compl Altern Med. 2009;5(7):49-58

22. Ogunlana OE, Ogunlana O, Farombi OE. Assessment of the scavenging activity of crude methanolic stem bark extract of Newbouldia laevis on selected free radicals. Adv Nat Appl Sci. 2008;2(3):249-54.

23. Kuete V, Eyong KO, Folefoc GN, Beng VP, Hussain H, Krohn K, Nkengfack AE. Antimicrobial activity of the methanolic extract and of the chemical constituents isolated from Newbouldia laevis. Pharmazie. 2007:62(7):552-6.

24. Abu AH, Uchendu CN. Safety assessment of aqueous ethanolic extract of Hymenocardia acida stem bark in Wistar rats. Arch Appl Sci Res. 2010;2(5):56-68.

25. Council for International Organizations of Medical Sciences (CIOMS). International Guiding Principles for Biomedical Research involving Animals. 1985. www.cioms.ch/publications/guidelines.

26. Edeoga $\mathrm{HO}, \mathrm{Okwu}$ DE, Mbaebie BO. Phytochemical constituents of some Nigerian medicinal plants. Afr J Biotechnol. 2005;4(7):685-8.

27. Kumar GS, Jayaveera KN, Kumar CKA, Sanjay UP, Swamy BMV, Kumar DVK. Antimicrobial effects of Indian medicinal plants against acne-inducing bacteria. Trop J Pharm Res. 2007;6:717-23.

28. Ayoola GA, Coker HAB, Adesegun SA, Adepoju-Bello AA, Obaweya K, Ezennia EC, Atangbayila TO. Phytochemical screening and antioxidant activities of some selected medicinal plants used for malaria therapy in southern Nigeria. Trop J Pharm Res. 2008;7(3):1019-24.

29. Reitman S, Frankel S. A colorimetric method for the determination of glutamic oxaloacetic and glutamic pyruvic transaminases. Am J Clin Pathol. 1957:28(1):56-63.

30. Szasz G. A kinetic photometric method for serum gamma glutamyl transpeptidase. Clin Chem. 1969;15(2):124-36.

31. Gornall AG, Bardawill CJ, David MM. Determination of serum proteins by means of the biuret reaction. J Biol Chem. 1949:177:751-6.

32. Doumas BT, Watson WA, Briggs HG. Albumin standard and the measurement of serum albumin with bromocresol green. Clin Chim Acta. 1971;31(1):87-96.

33. Bartels $\mathrm{H}$, Bohmer $\mathrm{M}$, Heierli C. Serum creatinine determination without protein precipitation. Clin Chim Acta. 1972;37:193-7.

34. Fawcett JK, Scott JE. A rapid and precise method for the determination of urea. J Clin Pathol. 1960;13:156-9.

35. Koide H, Oda T. The pathological occurrence of glucose-6-phosphatase in serum in liver diseases. Clin Chim Acta. 1959:4(4):554-61.

36. Misra HP, Fridovich I. The role of super oxide anion in the autoxidation of epinephrine and a simple assay for super oxide dismutase. J Biol Chem. 1972;247(10):3170-5

37. Sinha AK. Colorimetric assay of catalase. Anal Biochem 1972; 47(2):389-394. https://doi.org/10.1016/0003-2697(72)90132-7.

38. Tappel AL. Glutathione peroxidase and hydroperoxides. Methods Enzymol 1978; 52:506-513. https://doi.org/10.1016/s0076-6879(78)52055-7.

39. Chi-Yu L, Lynt J, Richard HC, James DM. Mouse liver glutathione-Stransferase. J Biol Chem. 1981;256:8110-6. 
40. Satoh K. Serum lipid peroxide in cerebrovascular disorders determined by a new colorimetric method. Clin Chim Acta 1978; 90:37-43. https://doi.org/10 1016/0009-8981(78)90081-5.

41. Ellman GL. Tissue sulfhydryl groups. Arch Biochem Biophys 1959; 82:70-77. https://doi.org/10.1016/0003-9861(59)90090-6.

42. Halliwell B, Gutteridge JMC. Free radicals in biology and medicine. 4th ed. Oxford: Clarendon press; 2007.

43. Oyedemi OS, Bradley G, Afolayan AJ. In vitro and in vivo antioxidant activities of aqueous extract of Strychnos henningsil Gilg. Afr J Pharm Pharmacol. 2010;4:70-8.

44. Lobo V, Patil A, Phatak A, Chandra N. Free radicals, antioxidants and functional foods: Impact on human health. Pharmacog Rev. 2010; 4(8):118126. https://doi.org/10.4103/0973-7847.70902.

45. Kumashiro N, Tamura Y, Uchida T, Ogihara T, Fujitani Y, Hirose T, Mochizuki $\mathrm{H}$, Kawamori R, Watada H. Impact of oxidative stress and peroxisome proliferator-activated receptor $\gamma$ coactivator-1a in hepatic insulin resistance. Diabetes. 2008; 57(8): 2083-2091. https://doi.org/10.2337/db08-0144.

\section{Publisher's Note}

Springer Nature remains neutral with regard to jurisdictional claims in published maps and institutional affiliations.

\section{Submit your manuscript to a SpringerOpen ${ }^{\circ}$ journal and benefit from:}

- Convenient online submission

- Rigorous peer review

- Open access: articles freely available online

High visibility within the field

- Retaining the copyright to your article

Submit your next manuscript at $\boldsymbol{\nabla}$ springeropen.com 